\title{
Nearly one-half of Brazilian patients with multiple sclerosis using natalizumab are DNA-JC virus positive
}

\author{
Cerca de metade dos pacientes brasileiros recebendo natalizumabe \\ para tratamento de esclerose múltipla tem DNA-JC vírus positivo \\ Yara Dadalti Fragoso', Maria Fernanda Mendes², Walter Oleschko Arruda, \\ Jefferson Becker ${ }^{4}$, Joseph Bruno Bidin Brooks', Margarete de Jesus Carvalho ${ }^{5}$, \\ Elizabeth Regina Comini-Frota ${ }^{6}$, Renan Barros Domingues ${ }^{7}$, \\ Maria Lucia Brito Ferreira ${ }^{8}$, Alessandro Finkelsztejn ${ }^{9}$, Paulo Diniz da Gama ${ }^{10}$, \\ Sidney Gomes ${ }^{11}$, Marcus Vinicius Magno Gonçalves ${ }^{12}$, \\ Damacio Ramon Kaimen-Maciel ${ }^{13}$, Rogério de Rizo Morales ${ }^{14}$, \\ Andre Muniz ${ }^{15}$, Heloisa Helena Ruocco ${ }^{16}$, Pedro Rippel Salgado ${ }^{17}$, \\ Livia Brito Bezerra de Albuquerque ${ }^{8}$, Rodrigo Assad Diniz da Gama ${ }^{10}$, \\ Sergio Georgeto ${ }^{13}$, Josiane Lopes ${ }^{13}$, Celso Luis Silva Oliveira ${ }^{1}$, \\ Francisco Tomaz Meneses Oliveira ${ }^{11}$, Juliana Safanelli², \\ Patricia Correia de Oliveira Saldanha7 ${ }^{7}$ Massaco Satomi ${ }^{17}$
}

\begin{abstract}
Objective: Natalizumab is a new and efficient treatment for multiple sclerosis (MS). The risk of developing progressive multifocal leukoencephalopathy (PML) during the use of this drug has created the need for better comprehension of JC virus (JCV) infection. The objective of the present study was to assess the prevalence of JCV-DNA in Brazilian patients using natalizumab. Method: Qualitative detection of the JCV in the serum was performed with real-time polymerase chain reaction (PCR). Results: In a group of 168 patients with MS who were undergoing treatment with natalizumab, JCV-DNA was detectable in 86 (51.2\%) patients. Discussion: Data on JCV-DNA in Brazil add to the worldwide assessment of the prevalence of the JCV in MS patients requiring treatment with natalizumab.
\end{abstract}

Keywords: JC virus, multifocal leukoencephalopathy, multiple sclerosis, natalizumab.

\footnotetext{
'Universidade Metropolitana de Santos, Santos SP, Brasil;

${ }^{2}$ Santa Casa de São Paulo, São Paulo SP, Brasil;

${ }^{3}$ Universidade Federal do Paraná, Curitiba PR, Brasil;

${ }^{4}$ Pontifícia Universidade Católica do Rio Grande do Sul, Porto Alegre RS, Brasil;

${ }^{5}$ Fundação ABC, Santo Andre SP, Brasil;

${ }^{6}$ Universidade Federal de Minas Gerais, Belo Horizonte MG, Brasil;

${ }^{7}$ Health Sciences Faculty, Santa Casa de Vitória, Vitória ES, Brasil;

${ }^{8}$ Hospital da Restauração, Recife PE, Brasil;

${ }^{9}$ Hospital de Clínicas de Porto Alegre, Porto Alegre RS, Brasil;

${ }^{10}$ Pontifícia Universidade Católica de São Paulo, Campus Sorocaba, Sorocaba SP, Brasil;

${ }^{11}$ Hospital Beneficência Portuguesa and Hospital Paulistano, São Paulo SP, Brasil;

${ }^{12}$ Universidade da Região de Joinville, Joinville SC, Brasil;

${ }^{13}$ Universidade Estadual de Londrina, Londrina PR, Brasil;

${ }^{14}$ Universidade Federal de Uberlândia, Uberlândia MG, Brasil;

${ }^{15}$ Hospital São Rafael, Salvador BA, Brasil;

${ }^{16}$ Multiple Sclerosis Center of Jundiaí, Jundiaí SP, Brasil;

${ }^{17}$ Universidade Federal de Mato Grosso do Sul, Campo Grande MS, Brasil.
}

Correspondence: Yara Dadalti Fragoso; Departamento de Neurologia da Faculdade de Medicina, UNIMES; Rua da Constituição 374; 11015 -470 Santos SP Brasil; E-mail:yara@bsnet.com.br

Conflict of interest: There is no conflict of interest to declare.

Received 02 May 2013; Received in final form 28 May 2013; Accepted 04 June 2013. 


\section{RESUMO}

Objetivo: Natalizumabe é um tratamento novo e eficaz para esclerose múltipla (EM). O risco constatado de desenvolver leucoencefalopatia multifocal progressiva (LEMP) durante o uso desta droga criou a necessidade de melhor estudar a infecção pelo vírus JC (JCV). 0 objetivo do presente estudo foi avaliar a prevalência de DNA-JCV em paciente brasileiros usando natalizumabe. Método: Detecção qualitativa de JCV no soro foi realizada através de reação em cadeia por polimerase (PCR) em tempo real. Resultados: DNA-JCV foi detectado em 86 pacientes $(51,2 \%)$ de um grupo de 168 pessoas com EM recebendo tratamento com natalizumabe,). Discussão: Dados do DNA-JCV no Brasil complementam as avaliações mundiais sobre a prevalência de JCV em pacientes com EM que necessitam tratamento natalizumabe.

Palavras-chave: esclerose múltipla, natalizumabe, JC vírus, leucoencefalopatia multifocal progressiva.

The recent advent of new drugs for treating multiple sclerosis (MS) did not come without associated risks. Multiple sclerosis is a chronic neurological disease with inflammatory and degenerative components, which makes this condition an important and prevalent cause of non-traumatic neurological disability in young adults ${ }^{1}$. Monoclonal antibodies such as natalizumab are now well established for MS treatment $^{2}$, and are part of the treatment protocol proposed by the Brazilian Ministry of Health. Fatal cases of progressive multifocal leukoencephalopathy (PML) related to John Cunningham virus (JCV) infection during natalizumab treatment have been described ${ }^{3}$. Therefore, special care and attention are required when using this drug. Progressive multifocal leukoencephalopathy occurs primarily in patients who are seropositive for the JCV and who have already received previous treatment schemes with immunosuppressive drugs ${ }^{4}$.

The prevalence of antibodies against the JCV in the general population is not well defined. Some authors have suggested that up to $80 \%$ of individuals worldwide have been in contact with the JCV and have developed antibodies that are detectable in their blood ${ }^{5}$. Other authors have shown that subclinical reactivation of the JCV changes and increases when patients start on natalizumab therapy ${ }^{6}$. Despite the inherent concerns in relation to JCV positivity among patients with MS who are starting on natalizumab therapy, there are surprisingly few studies discussing this point. It has been reported that $58.8 \%$ of German MS patients are seropositive for the $\mathrm{JCV}^{7}$, and that $51 \%$ of French MS patients are seropositive for the JCV ${ }^{8}$. Both studies were very recent, and no other country has published results from their databases on the presence of JCV among MS patients taking natalizumab.

The prevalence of JCV deoxyribonucleic acid (JCV-DNA) detection is unknown among Brazilian patients receiving natalizumab. The aim of the present study was to gather data from several Brazilian centers for MS diagnosis and treatment to understand the prevalence of JCV-DNA among our patients.

\section{METHODS}

This study was approved by the Ethics Committee of Universidade Metropolitana de Santos as a study on drugs for the treatment of MS (Number CAAE 05669912.3.0000.5509). Additional approval from other MS centers was obtained, whenever necessary, by the neurologists in charge of their patients.

Qualitative detection of the JCV in serum was performed by real-time polymerase chain reaction (PCR) with a detection limit of 620 copies/mL. Patients with detectable JCV in the serum were considered "JCV-DNA positive". This test was always performed by the same laboratory in accordance with the STRATIFY-JCV program, which was organized and funded by Biogen Idec. The data were gathered from neurologists and health care providers involved in natalizumab infusions. These professionals formed an independent Brazilian group of neurologists working in several aspects of MS. Additional information obtained for each patient included gender, age, and information on previous treatment with immunosuppressive drugs. The results were essentially analyzed in a descriptive manner.

\section{RESULTS}

Results were obtained from investigations on JCV-DNA viremia in 168 patients undergoing MS treatment with natalizumab. The patients were from $17 \mathrm{MS}$ units in nine Brazilian states. These 168 patients on natalizumab had experienced therapeutic failure with interferon beta and/or glatiramer acetate. The patients' previous therapeutic failure most frequently was in relation to both of the aforementioned immunomodulatory drugs.

These patients comprised 111 females and 57 males. They had an average age of $41.2 \pm 10.8$ years. The JCV-DNA was detectable in $86(51.2 \%)$ patients. There was no correlation between JCV-DNA positivity and gender, age, or treatment duration. The average length of natalizumab use was $11.2 \pm 6.2$ months (range, 1-44 months). Previous use of immunosuppressive drugs was observed in $24 \%$ of the 168 patients. In considering only the patients who were positive for JCV-DNA, 22 patients had used immunosuppressive drugs before the prescription of natalizumab (i.e. $25.6 \%$ of the JCV-DNA-positive patients). No cases of PML were observed in these patients. All doctors participating in this study were aware of the risks of PML in relation to the JCV and to the previous use of immunosuppressive drugs. 


\section{DISCUSSION}

The present study is very relevant since only two previous papers have reported JCV serology among MS patients undergoing treatment with natalizumab. The published reports show that $51 \%$ to $58.8 \%$ of these patients are seropositive for the JCV ${ }^{7,8}$. The results from this Brazilian population showed a similar prevalence: approximately one-half of the patients with MS receiving natalizumab were positive for JCV-DNA. The prevalence of JCV in patients with MS in France, Germany, and Brazil is considerably less than the $80 \%$ suggested by other authors ${ }^{5}$. However, different methods were used to assess JCV in the various studies. Other countries should follow soon with the publication of their data to help assess the worldwide prevalence of JCV in MS patients requiring treatment with natalizumab. In understanding the serum anti-JCV status of MS patients, clinicians also need to know that this result underestimates infection levels since the false negative rates have been calculated as high as $37 \%^{9}$. This additional fact, recently reported in the literature, states that a negative JCV antibody result should not be conflated with absence of JCV infection'. In fact, there are reports of PML caused by the JCV in natalizumab-treated patients with negative JCV test results ${ }^{10}$.

Brazilian neurologists are well aware of the risks for patients who are JCV-DNA-positive and have used immunosuppressive drugs in the past. With the patient's agreement, they are nonetheless prescribing natalizumab in patients who have had therapeutic failure with immunomodulatory drugs. It is imperative that continuous medical education programs and pharmacovigilance databases are maintained in Brazil since the use of natalizumab has become more frequent ${ }^{11}$.

\section{References}

1. Dutta R, Trapp BD. Mechanisms of neuronal dysfunction and degeneration in multiple sclerosis. Prog Neurobiol 2011;93:1-12.

2. Rudick R, Polman C, Clifford D, Miller D, Steinman L. Natalizumab: bench to bedside and beyond. Arch Neurol 2012;5:1-11.

3. Kleinschmidt-DeMasters BK, Miravalle A, Schowinsky J, Corboy $J$, Vollmer T. Update on PML and PML-IRIS occurring in multiple sclerosis patients treated with natalizumab. J Neuropathol Exp Neurol 2012;71:604-617.

4. Sørensen PS, Bertolotto A, Edan G, et al. Risk stratification for progressive multifocal leukoencephalopathy in patients treated with natalizumab. Mult Scler 2012;18:143-152.

5. Berger JR, Houff S. Progressive multifocal leukoencephalopathy: lessons from AIDS and natalizumab. Neurol Res 2006;28:299-305.

6. Khalili K, White MK, Lublin F, Ferrante P, Berger JR. Reactivation of $\mathrm{JC}$ virus and development of PML in patients with multiple sclerosis. Neurology 2007;68:985-990.
7. Trampe AK, Hemmelmann C, Stroet A, et al. Anti-JC virus antibodies in a large German natalizumab-treated multiple sclerosis cohort. Neurology 2012;78:1736-1742.

8. Outteryck O, Ongagna JC, Duhamel A, et al. Anti-JCV antibody prevalence in a French cohort of MS patients under natalizumab therapy. J Neurol 2012;259:2293-2298.

9. Berger JR, Houff SA, Gurwell J, Vega N, Miller CS, Danaher RJ. JC virus antibody status underestimates infection rates. Ann Neurol 2013 Mar 22 [E-pub].

10. Mazda ME, Brosch JR, Wiens AL, et al. A case of natalizumabassociated progressive multifocal leukoencephalopathy with repeated negative CSF JCV testing. Int $J$ Neurosci 2013;123:353-357.

11. Fragoso YD, Alves-Leon SV, Arruda WO, et al. Natalizumab adverse events are rare in patients with multiple sclerosis. Arq Neuropsiquiatr 2013;71:137-141. 